\title{
Gastro-Intestinal Melanoma Metastases: Historical Dimensions
}

Wilson I. B. Onuigbo

Department of Pathology, Medical Foundation and Clinic, 8 Nsukka Lane, Enugu, Nigeria

\begin{abstract}
An admirable adage is the desirability of being knowledgeable about the data dating to yester years. Perhaps, it was the acknowledgeable account of such a dictum that made a group to research on the pigment cell biology in terms of the melanoma. However, the important field of gastro-intestinal melanoma metastases could not be found in their presentation. Accordingly, this paper sets out to correct the omissions. It was found that, with the obvious assistance of the pigmentation of the melanoma, the medical masters of yester years showed their mettle regarding the invasion of the gastro-intestinal tract.
\end{abstract}

Keywords: Melanoma, stomach; intestine, spread, history

\section{INTRODUCTION}

In the opinion of the Australian research giant, Macfarlane Burnet, ${ }^{1}$ present papers must be written with full awareness of the past publications. In order to follow this theme ${ }^{2}$, Nordlund's associates attempted to provide particular details, but must have failed, despite their wide coverage subtitled "THE EARLY STUDIES: PRE-1900." Accordingly, I resorted to the authoritative Transactions of the Pathological Society of London which began publications in the 1846-48 period. ${ }^{3}$ Therefore, numerous cases of the Transactions were searched and documented vis-a-vis the gastro-intestinal tract.

\section{HISTORICAL TEXTS}

The stomach was searched thoroughly and found to be uninvolved; the rest of the tract was also not affected in the opinion of Beadles. ${ }^{4}$ In the words of Coupland, "The stomach and intestine were natural. No growths or ulceration in connection with them in any part."

Coming to details, Fagge $^{6}$ described an interesting case thus:

The mucous membrane of the stomach was plentifully sprinkled over with black spots, some very minute, others as large as millet seeds. They were not in the least raised above the level of the rest of the surface.

$\operatorname{Legg}^{7}$ was observant having detected much dilated stomach with "a small new growth in mucous membrane, size of spit peas." He also specified that the pylorus was free. Furthermore, he remarked, "The bowels show, where the mesentery is attached, innumerable new growths, the size of spit pea."

Mackenzie, ${ }^{8}$ after dilating on the omenta, specified that, on the serous layers of the intestines and stomach, "there is only a speck of the smaller size seen here and there."

On their part, Calvert and $\mathrm{Pigg}^{9}$ included affected stomach and intestines from a long list of colonized parts. Indeed, they went to the extent of listing in order the organs collected from a series of the Transactions. While liver topped the list with 19 cases, the stomach came low down with only 2 cases. Incidentally, they revealed that their exhibited specimens "were fixed in formalin and mounted in glicerine - a process begun at St. Bartholomew's and introduced into England by Dr. Kantack."

Rolleston ${ }^{10}$ was interested in progression from "minute" metastases to "polypoid" ones. Similarly, that some parts of the gastro-intestinal tissues may be selected for attack were appreciated by Ogle. ${ }^{11}$ 
Wilson I. B. Onuigbo, "Gastro-Intestinal Melanoma Metastases: Historical Dimensions"

More extensive coverage came from Thomson ${ }^{12}$ as follows:

There were twenty large secondary growths in the small intestine; the smallest was about the size of a marble, while the largest was about as big as a pigeon's egg. All these were growing into the lumen of the bowel, and only showed externally as small dark depressions which gave no idea whatever of their actual appearance or size. These were entirely confined to the small intestine; the uppermost one was situated at the end of the duodenum, and the lowest one was at the ileo-cæcal valve, while they were most numerous in the upper part of the jejunum. There was a varying amount of pigmentation present, and some hæmorrhage had occurred into the substance of some of them.

\section{DISCUSSION}

There is no doubt that the literature on the history of medicine is growing. Thus, published materials are so variegated as to involve bone,${ }^{13}$ thyroid,${ }^{14}$ ophthalmology, ${ }^{15}$ orthopedics, ${ }^{16}$ plastic surgery, ${ }^{17}$ and colorectal surgery. ${ }^{18}$ Incidentally, in keeping with my avid assessment of the lingua franca status of English, ${ }^{19}$ it is evident from their deft descriptions that the medical masters of yester years were knowledgeable in autopsy work.

In conclusion, this statement is in keeping with the 1889 precepts of Julius Cohnheim, ${ }^{20}$ a great German pathologist. As he advocated, autopsies "are all in a manner experiments instituted by nature, which we need only rightly interpret to get a clear idea of the causes, laws of growth, and significance of the tumour." I am persuaded, therefore, that autopsy provided enough data used in presenting adequate historical dimensions of the spread of melanoma to the gastro-intestinal tract.

\section{REFERENCES}

[1] Macfarlane B. Morphogenesis in cancer. Med J Aust, 1977; i: 5-9.

[2] Nordlund JJ, Abdel-Malek ZA, Boissy RE, et al. Pigment cell biology: An historical review. J Invest Dermatol, 1989; 92:53S-60S.

[3] Anonymous. BYE-LAWS AND REGULATIONS. Trans Path Soc Lond, 1840-48; 1:15.

[4] Beadles CF. A case of multiple malignant growths. Trans Path Soc Lond, 1894; 45: 188-197.

[5] Coupland S. Primary diffuse malignant growth in the liver, in which the characters of sarcoma and cacinoma were apparent. Trans Path Soc Lond, 1880; 31:130-135.

[6] Fagge $\mathrm{CH}$. Two cases of melanuria associated with melanotic new growths. Trans Path Soc Lond, 1877; 28:172-175.

[7] Legg JW. Melanotic sarcoma of the eyeball; secondary growths in the organs of the chest and belly, particularly in the liver. Trans Path Soc Lond, 1878; 29:225-229.

[8] Mackenzie J. Melanotic sarcoma, very widely disseminated. Trans Path Soc Lond, 1891; 42:321329.

[9] Calvert J, Pigg S. A case of melanotic sarcoma. Trans Path Soc Lond, 1898; 49:297-299.

[10] Rolleston HD. Secondary polypoid melanotic tumours in the mucosa of the small intestine. Trans Path Soc Lond, 1897; 48: 82-83.

[11] Ogle JW. Melanotic carcinomatous deposit connected with the dura mater, the lining of the ventricles, and the seventh and ninth pairs of cranial nerves. Trans Path Soc Lond, 1856; 7:5-8.

[12] Thomson HC. A case of melanotic sarcoma with secondary growths of unusual size in the small intestine. Trans Path Soc Lond, 1899; 50:236-239.

[13] Onuigbo WIB. Historical concepts of cancer metastasis with special reference to bone. Bone metastasis, edited by L. Weiss and H. A. Gilbert. Boston: G. K. Hall Publishers, Chapter 1, pp 110, 1981.

[14] Harwick RD. Our legacy of thyroid surgery. Am J Surg, 1988; 156:230-234.

[15] Winstanley J. Ophthalmology at St Thomas' Hospital, London: The 12th to the 19th centuries. Surv Ophthamol, 1978; 22:341-347.

[16] Beasly AW. The origins of orthopaedics. J Roy Soc Med, 1982; 75:648-655. 
Wilson I. B. Onuigbo, "Gastro-Intestinal Melanoma Metastases: Historical Dimensions"

[17] Bennett JP. Aspects of the history of plastic surgery since the 16th century. J Roy Soc Med, $1983 ; 76: 152-157$.

[18] Graney MJ, Graney CM. Colorectal surgery from antiquity to the modern era. Dis Col Rec, 1980; 23:432-441.

[19] Onuigbo WIB. The word "uneventful" exemplifies the lingua franca status of English. World Journal of Developing Country Education and Research, 2014; 1: 1-5.

[20] Cohnheim J. Lectures on general pathology. Section 1. London. The New Sydenham Society. $1889 ;$ p.14.

Citation: I. B. Onuigbo W. Gastro-Intestinal Melanoma Metastases: Historical Dimensions. International Journal of Research Studies in Medical and Health Sciences. 2017; 2(2):1-3.

Copyright: (c) 2017 I. B. Onuigbo W. This is an open-access article distributed under the terms of the Creative Commons Attribution License, which permits unrestricted use, distribution, and reproduction in any medium, provided the original author and source are credited. 